\title{
Digital Agriculture: Possibilities For Agricultural Insurance Evolution
}

\author{
Tatiana V. Skryl* \\ Department of Economic Theory \\ Plekhanov Russian University of Economics \\ Moscow, Russia \\ t_skryl@mail.ru
}

\author{
Vladimir S. Osipov \\ Department of Risk Management and Insurance \\ MGIMO University, \\ Institute of Market Problems \\ Russian Academy of Science \\ Moscow, Russia \\ vs.ossipov@gmail.com
}

\author{
Sergey V. Zhevora \\ All-Russian Research Institute of Potato farming by A.G. Lorh \\ Moscow, Russia \\ zhevoraserg@yandex.ru
}

\begin{abstract}
The digital economy is gaining momentum. Nowadays it being formed institutional conditions for the implementation of the transition to new technologies using the Internet of Things. A roadmap for the introduction of the Internet of Things in the agro-industrial complex has been considered. The regulatory and legal framework of agrarian policy, the objectives of its implementation and regulation of markets for agricultural products, raw materials and foodstuffs are noted in the context of increasing labor productivity in the Russian Federation. The digital economy as a trend has affected the sphere of the agro industrial complex. The authors show the main provisions of the road map, both in terms of the proposed tax breaks and the extension of agricultural insurance in conjunction with government subsidies for the expansion of the Internet infrastructure of things. The author pays attention to the participation of small agricultural producers in the implementation of the proposed roadmap, which due to their scale of production, as well as high one-time capital expenditures for the transformation of the production process, may not take advantage of new production technologies. In summary, the main provisions of the law on state support in the field of agricultural insurance, the rights and obligations of the parties to the contract of agricultural insurance are advised.
\end{abstract}

Keywords-Digital agriculture; Agricultural insurance; Agrarian policy; Internet of things; Public administration in agriculture; State subsidies

\section{INTRODUCTION}

In accordance with Art. 5 of the Federal Law No. 264-FZ of December 29, 2006 "On the Development of Agriculture", state agrarian policy is an integral part of the state social and economic policy aimed at sustainable development of agriculture and rural areas. Since agrarian policy is a part of state social and economic policy, it must obey the general principles of the latter's formation.

The agrarian policy is expressed in a strategy to increase the efficiency of agricultural production, which in turn requires the protection of the economic interests of agricultural producers against the anti-competitive behavior of foreign farmers. Their behavior can be expressed not so much by prohibitive measures (contrary to WTO norms), but by special actions of the government aimed at increasing the efficiency of agricultural production.

\section{MATERIALS AND METHODS}

The main goal of the agrarian policy is to create such institutional conditions that would create a competitive product and strengthen the competitiveness of agricultural enterprises.

The principles of agrarian policy are reduced to a sequence of measures of state agrarian policy, institutionalization and targeting of state support, the formation of civilized market conditions in the agrarian products market, the openness of agrarian policy.

The main directions of the agrarian policy should be related to the protection of the interests of domestic agricultural producers and the formation of institutional conditions for sustainable development of the agrarian sector, which follows from the normative definition of agrarian policy.

One of the main trends of the institutional economic policy of modern Russia is the transition to digital production technologies, the digitization of the economy.

Digitalization is widely represented in the scientific literature, with the greatest attention paid to financial issues crypto-currencies [1], slightly less - to blocking technologies [2]. However, these elements are not limited to the digital economy. The so-called "Internet of Things" (Internet of Things, IoT) has a great influence on the reorganization of business processes and production technologies[3,4].

On the other hand an agriculture is known to be one of the most risky activities. Adverse weather conditions or epizootics can cause irreparable damage to such activities up to the bankruptcy of the agricultural producer. The development of crop insurance is designed to hedge the risks of loss or 
livestock. Insurance is used in some types of economic relations quite widely, regulating the likely negative consequences for economic activity of natural disasters, accidents, etc.

In 2016, the insurance of risks in agriculture in the Russian Federation carried out by 45 insurance companies, 23 of whom the insurer has entered into contracts of insurance with state subsidies for agricultural producers.

As shown by both Russian and foreign practice of agriculture has always needed the support of the state, because, first, the provision of food provides food security of the country, and secondly, the industry due to the high risk production activity has not such a high investment of resources, such as the financial sector.

\section{Authors' calculations}

Table I shows a noticeable uneven development of the agricultural insurance market, the volume of which varies depending on the degree of volatility of the Russian economy. If we compare the amount of money paid in comparison with the collected funds, we will see an interesting picture.

TABLE I. AGRICULTURAL INSURANCE IN THE RUSSIAN FEDERATION

\begin{tabular}{|c|c|c|c|c|c|}
\hline $\begin{array}{c}\text { Indicator, } \\
\text { million } \\
\text { rubles }\end{array}$ & 2012 & 2013 & 2014 & 2015 & 2016 \\
\hline $\begin{array}{l}\text { Insurance } \\
\text { premiums } \\
\text { (contribution } \\
\text { s) collected } \\
\text { by insurers }\end{array}$ & 10257,0 & 12079,4 & 14696,5 & 9943,8 & $\begin{array}{l}10014, \\
9\end{array}$ \\
\hline $\begin{array}{l}\text { Payments } \\
\text { under } \\
\text { insurance } \\
\text { contracts } \\
\text { made by } \\
\text { insurers }\end{array}$ & 6712,8 & 4872,4 & 4866,7 & 4023,2 & 4051,7 \\
\hline $\begin{array}{l}\text { The } \\
\text { percentage of } \\
\text { payments to } \\
\text { the collected } \\
\text { contributions } \\
, \% \\
\text { overwhelmin } \\
\text { g }\end{array}$ & 65,45 & 40,34 & 33,11 & 40,46 & 40,46 \\
\hline
\end{tabular}

\section{RESULTS AND DISCUSSION}

The change of institutional environment of Russian economy development and implementation of the trend to digitization of the economy may adjust the position of agricultural producers and pay more attention to the system of agricultural crop insurance.

In July 2016 during the "Innoprom" exhibition the Chairman of the Government of Russia D.A. Medvedev reported on the preparation of a regulatory framework for this technology. That is why the close attention of this technology should be given by scientific society.

The roadmap for the introduction of the Internet of things in the agro-industrial complex has already been developed and is being negotiated in the relevant ministries and departments. It is important to note that not only ministries and departments took part in the development of the road map, as it usually happens, but also non-profit organizations and universities, in particular, the Russian State Agrarian University named after K.A. Timiryazev.

The road map provides the tax incentives - a reduction in the single agricultural tax (now its rate is $6 \%$ ) by increasing the deduction of costs for the introduction and use of new technologies, as well as stimulating the development of communication infrastructure and the Internet. Because of the implementation of the road map in 2 years, about a third of the enterprises of the agro-industrial complex will use the Internet of things in production and economic activities. It is important to note that the Internet of things for enterprises of the agroindustrial complex can give an impetus to the development of related industries. The increase in the efficiency of the enterprises of the agro-industrial complex will be accompanied by the expansion of the activity of the telecommunications business and the electronics industry.

Increasing the efficiency of production activities based on the Internet of things is possible at the expense of increasing the yield of crops, monitoring the status of milking flocks or poultry houses, etc[5].

The most vivid example of the effective use of the Internet of things can be the products of John Deer [6]. The company actively uses an innovative approach to the development of technologies and to agriculture as an industry as a whole. The company uses a GPS navigation system, as well as a mass of sensors on its combines. The combine can determine the content of the oil in grains, separate the crop from the weed, the unevenness of the soil, the humidity level, etc. Getting such information saves processing time, fuel, labor, and hence, the growth of gross production and labor productivity. New technologies allow controlling the condition of internal units and mechanisms of the machine and preventing expensive repairs during the height of agricultural work. Moreover, the system is capable of self-learning and adapts to the individual needs of the farmer and the characteristics of farmland. The combine operates in automatic mode, without human use by restricting the area of use; thus, the possibility of moving the combine beyond the boundaries of the land plot is excluded. In addition, the Internet forum system unites farmers-users of equipment and allows them to communicate with each other, share experiences, access to the most important information on the state of soils in different territories, the parameters of laying seeds and fertilizers, the impact on yields of moisture and nutrients in the soil and seeds, etc. In the same community, farmers exchange knowledge and technological subtleties, improving their collective experience. This system turns a farmer into the centerpiece of the value chain, around which value is formed, protects, as farmers report "... my farm, my work, productivity and my unique experience" [6]. John Deere himself, the founder of the company, said: "I will never put my name on a product that does not have the best that is in me." Until now, these words are the motto of the company, but it is constantly filled with new content. The whole process of innovation is aimed at satisfying the needs of the consumer, not only the product itself and its characteristics, but the accumulated knowledge, related services and group access to 
the Deere data bank for answers to a wide variety of questions. When a farmer needs advice, they can contact each other across the country. According to the information received, the farmer can independently determine what he or she will be affected by a particular product or service. The choice always remains in the competence of the farmer, not the company, which is typical for most manufacturers of a wide variety of products.

Thus, the consumer is at the center of the value creation process, and companies, their employees and technologists only support it. Participants have the opportunity to communicate with each other in the value chain, negotiate with each other, interact with each other, which makes the life of the end user more productive, the activity is effective. It is more convenient for a consumer to satisfy his needs, for which he will be grateful to the company, returning to it for a new product [7].

John Deere says: "We work for your profit, success, and for you to always be on top!"[6]

John Deere's example shows that the Internet of things allows not only to meet the needs of consumers-farmers in the effective use of agricultural machinery, but also to rebuild business processes so that the increase in production efficiency is accompanied by a reduction in costs. Russian agricultural commodity producers are more cautious in changing their business processes, but understanding the need to look for ways to increase the economic efficiency of activities makes them look for new ways of realizing this goal. There are already examples of successful introduction of the Internet of things into production processes, for example, for monitoring the status of milking flocks, monitoring of poultry houses. While these technologies can be realized in the largest agricultural producers due to high one-time capital expenditures for infrastructure. That is why state intervention was needed to create such institutional conditions that would allow using advanced technologies for a larger range of agricultural producers.

In addition to tax incentives, the road map provides for changing institutional conditions for the development of the infrastructure of communication facilities, in particular, simplifying the procedure for building infrastructure facilities on agricultural land.

The road map contains another important institutional change related to the provision of government subsidies. So, they will now be provided only to those agricultural producers who insure their crops using automated continuous monitoring. From this, of course, serious changes in the structure of the agricultural raw materials market are also possible, since small producers can not afford agricultural insurance using automatic continuous monitoring, since this is due to large single payments, which will lead to an even greater monopolization of the market. It is possible and to avoid this risk if payment of insurance for small agricultural commodity producers should be delayed, however, it is not known whether insurers will take such a step.

According to the IAMO[8], the introduction of technologies based on the Internet of things on average increases the efficiency of agricultural production by $20-30 \%$, depending on the type of activity and technologies used and the culture of agricultural technology.

In a dispute with the Ministry of Finance of the Russian Federation on reducing the rate of unified agricultural tax due to the cost of implementing such technologies, the argument would be to increase labor productivity in the industry. We realize that the Ministry of Finance of the Russian Federation will most likely refuse to agree on any tax cuts, as this does not fit into the long-term fiscal policy pursued by the ministry. However, this is not an excuse to refuse to collect arguments in favor of raising the labor productivity required to achieve The Government of the Russian Federation as a whole within the framework of the national project. The Presidium of the Council for Strategic Development and Priority Projects on August 30, 2017 approved the passport of a new priority area "Increasing labor productivity".

Returning to farmers and other small agricultural producers, we should note one more concern for their fate because of the implementation of the proposed roadmap. Distribution of subsidies to agricultural producers is already uneven, depending on the size of the enterprise $[9,10]$.

\section{CONCLUSION}

Nowadays, agro insurance is not mandatory for agricultural producers $[11,12]$, but if, the situation drastically changes, the economies of scale will not allow small agricultural producers to continue their activities. At least, it can be predicted a significant deterioration in working conditions for them, since state subsidies per hectare for small forms of organizations will give a small financial result, and taking into account compulsory agricultural insurance can all to bring it to nothing. Another problem is the obvious dysfunction of public administration - lobbying opportunities for big business. If state subsidies for agricultural commodity producers were distributed without taking into account the lobbying capacity of large agricultural holdings, it is possible that small commodity producers were also able to obtain the effect of agro insurance in exchange for subsidies and introduction of technologies based on Internet stuff. At present, in order to implement the prospective road map so as not to allow the ruin of small agricultural producers, we should carefully discuss with the expert community, industry associations and representatives of small agricultural producers the proposed measures and work out mechanisms for leveling possible risks.

\section{REFERENCES}

[1] P. Vigna and M. Casey, The Age of Crytocurrency: How bitcoin and the blockchain are challenging the global Economic order, New York, St. Martin's Press,2015, pp. 233

[2] M. Blockchain Swan, Blueprint for a New Economy. O’Reilly. Shema novoj jekonomiki, Olimp-Biznes, Moscow, 2017, pp. 240

[3] S. Greengard, The Internet of Things, Al'pina Pablisher, The MIT Press, 2015 , pp. 45

[4] T. Macaulay, RIoT Control. Understanding and Managing Risks and the Internet of Things [1 ed.], Morgan Kaufmann, 2017, pp. 107

[5] "Industrial Internet Insights Report for 2015" https://www.accenture.com 
[6] T. Peterson, Gazing into the Future with Deer's Top Ag Man, BusinessWeek, 2000, pp. 340

[7] L. Floridi, The 4th Revolution. How the Infosphere is Reshaping Human Reality, Oxford University Press, 2014, pp. 248.

[8] Leibniz Institute of Agricultural Development in Transition Economies https://www.iamo.de/

[9] T.V. Skryl, “A Paradigm Shift in Russia’s Industrial Policy: From a Raw Model to Innovative Technological Growth Points," International
Journal of Ecological Economics and Statistics, vol. 38(2), pp. 49-58, 2017.

[10] T.M. Vorozheykina, "Influence of Institutional Environment on the Competitiveness of Domestic Agriculture," AIC: Economics, management, vol. 2014(4), pp. 71-74, 2014.

[11] R.T. Yuldashev and L.I. Tsvetkova, Insurance Business Practice, Moscow, 2010, pp. 340

[12] S.V. Zhevora and V.S. Osipov, "Insurance of Crops and Harvest," Potatoes and Vegetables, vol. 2017(2), pp. 16-18, 2017. 